\title{
Analysis of Logistics Education in Poland: Present State and Prospects
}

\begin{abstract}
The research subject in this article is the analysis of the logistics education offer in Poland, the main specialities offered by universities and the prospects for young logistics professionals. The author analyses the situation of state and private universities in the field of logistics education and shows that a significant change has occurred in the number of specialities (an increasing trend) and that state universities are still leading the way in that regard. Higher education reform has expanded its offer of supplementary master's courses. Analysis of statistical data and the use of quantitative methods through the use of PAPI and CAWI techniques set the direction for further research. The article will aim at a more accurate analysis of logistics education in Poland by looking at the education offer including lyceum (high school), technical education and higher education as well as post-graduate studies and professional training. Verification of the above empirical research should take into account possible applications of logistics education per se.
\end{abstract}

Keywords: education in Poland; logistics; logistics education; logistics in Poland

Received: 25 October 2019

Accepted: 23 March 2020

\section{Sugerowana cytacja/Suggested citation:}

Maroń, J. (2020). Analysis of Logistic Education in Poland: Present State and Prospects. Przedsiębiorczość - Edukacja [Entrepreneurship - Education], 16(1), 173-183. doi: 10.24917/ 20833296.161.14

\section{Introduction}

What is the real situation on the labour market in the logistics sector? Is it worth studying logistics? To answer such questions it requires describing the Polish logistics market. The author has carried out research in Poland to analyse the actual offer and prospects for logistics education. The author has explored the subject to shed light on data, then described the findings of the exploration process and finally explained the reasons for certain circumstances and background. 
According to the work prepared by Ireneusz Fechner and Grzegorz Szyszka, 'Logistics in Poland, Report 2017, logistics constitutes an increasingly important sector of the Polish economy. In 2016-2017, the share for transport and logistics, of both goods and people in the GDP, amounted to $11.5 \%$, which translates into approximately PLN 228 million ${ }^{1}$. The numbers presented clearly show the size of this sector. Does this data make an argument for studying logistics and looking for lucrative contacts in this industry? This question will be answered by a detailed analysis of Polish logistics companies and companies with extensive logistics departments.

The logistics sector in Poland includes all bodies operating in the TLS (Transport Layer Security) sector, including logistics operators, forwarders, transport companies and fast-developing companies providing courier services (KEP - Courier, Express and Parcel shipments). There is no way that companies can create the entire logistics infrastructure and be responsible for systems, software and consulting. It follows that the labour market in this sector is much larger than it seems at first glance - undeniably it is created not only by logistics companies but also those in the entire spectrum of manufacturing and trade that are set up to provide efficient logistics of goods and services. Consultants of the Institute of Logistics and Warehousing in Poznań have conducted surveys over many years and the indicators proposed by them illustrate the condition of this sector and allow the problems facing enterprises operating in it to be understood (Fecher, Szyszka, 2017: 131).

PMI should be considered as the most significant factor describing the state of the economy, as it assesses the economic situation in given entities from the point of view of employees responsible for logistics and purchases. This indicator is created on the basis of continuous research in many countries for which IHS Markit is responsible. PMI in 2018 in the eurozone exceeded 50 points allowing the economic situation to be considered as growing. The last quarter of 2017 brought a score exceeding 55 points which only confirmed the satisfactory economic situation. The satisfying situation of Poland's neighbours translates directly into the Polish background and is reflected in the research (PMI for Poland in the same period was 53.06 which was the second-best result in its history). Such a good economic situation is certainly echoed in the logistics sector. From February 2015 , for the next 14 months, the increase in the number of orders received by Polish producers showed an unbroken upward trend (Fecher, Szyszka, 2017). Taking such data into account, it can be stated that for over three years, the condition of the Polish economy was improving strongly, and thus the volume of production, the level of employment and the number of new orders were increasing.

Is it worth studying logistics? It is worth presenting one more, very important, indicator proposed by the authors of the report Barriers to Business Development. As can be seen from the first part, the labour situation in the logistics market is constantly improving and it is difficult to talk about the developmental barriers that are important from the financial point of view. However, one particularly interesting point can be pointed out. GUS (Główny Urząd Statystyczny) statistics (published every year) point to employment problems as the main barrier to business development. Figure 1.1 presents the 10 -year-research results.

\footnotetext{
${ }^{1}$ www.businessinsider.pl entered: 1 March 2019
} 
Figure 1.1. Barriers to enterprise development related to employment and access to services in Poland

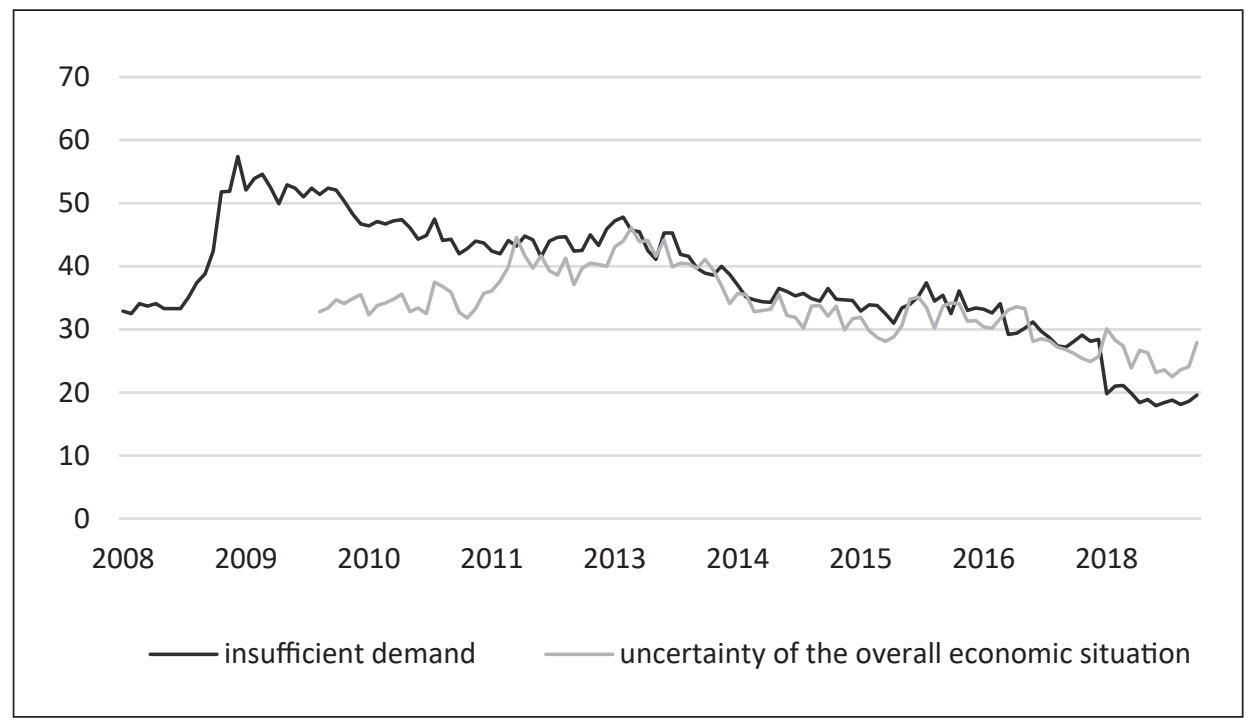

Source: Fecher, Szyszka (2017: 132)

Figure 1.1 clearly shows that the most important problem for enterprise development in the logistics sector has been the lack of availability of qualified employees for consecutive years. The surveyed managers indicated the biggest increase in the problem in 2017 when the rate increased from $30.5 \%$ to over $47 \%$. GUS data reveal that the problem of the logistics sector in Poland, without a doubt, was a shortage of qualified personnel (domestic specialists), thus companies are forced to employ qualified employees from abroad, associated with an increase in costs. In such a situation, an employee on the market who, having a certain competence package, can definitely count on very good remuneration. Are the problems related to staff shortages stated by managers reflected in the number of graduates of logistics majors at universities? Figure 1.2. presents the number of logistics graduates in 2012-2017.

The research results show that the number of logistics graduates is constantly growing, although this is not an increase corresponding to market demand. In the academic year 2016/2017, 54000 students were studying logistics. Unfortunately, precise statistics for the academic year 2017/2018 could not be found, yet taking into account an upward, almost linear trend, this may be about 55-56 000 students (Fecher, Szyszka, 2017). A very important aspect that is worth considering when planning a professional career is remuneration. The report Salaries in Logistics in 2017 issued by Sedlak \& Sedlak includes data on the wages of 11962 people working in the industry and in logistics departments (Figure 1.3). Unfortunately, the report shows that wages do not rank very highly. As many as $25.6 \%$ of the respondents earned slightly more than PLN 3061 gross. The median for men and women was PLN 4033 gross and 255 people earned no less than PLN 5645 gross (Sedlak, 2017). Consequently, remuneration also depends on other variable factors, such as company size, management level, type ownership, industry, department, age, education, foreign language skills and seniority, all of which were included in the report. 
Figure 1.2. Polish education logistic specialists in the years 2012-2017

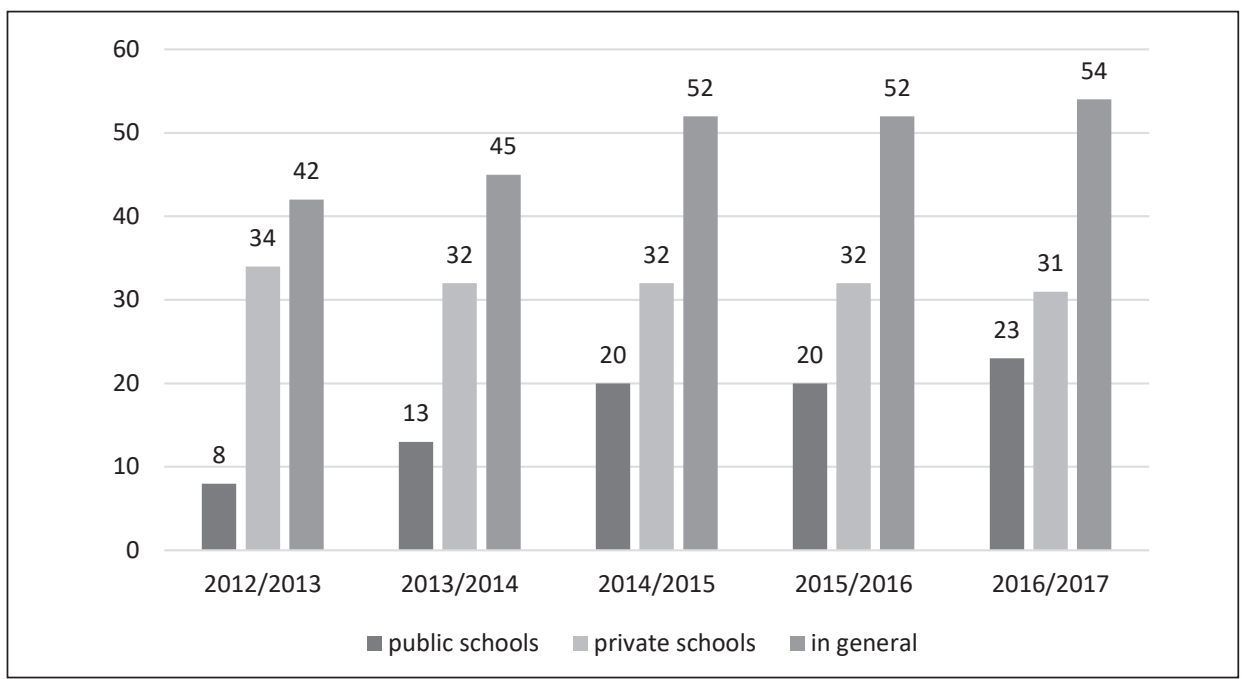

Source: Fechner, Szyszka (2017)

Figure 1.3. Salary Report for logistics in 2017 in Poland: by gender

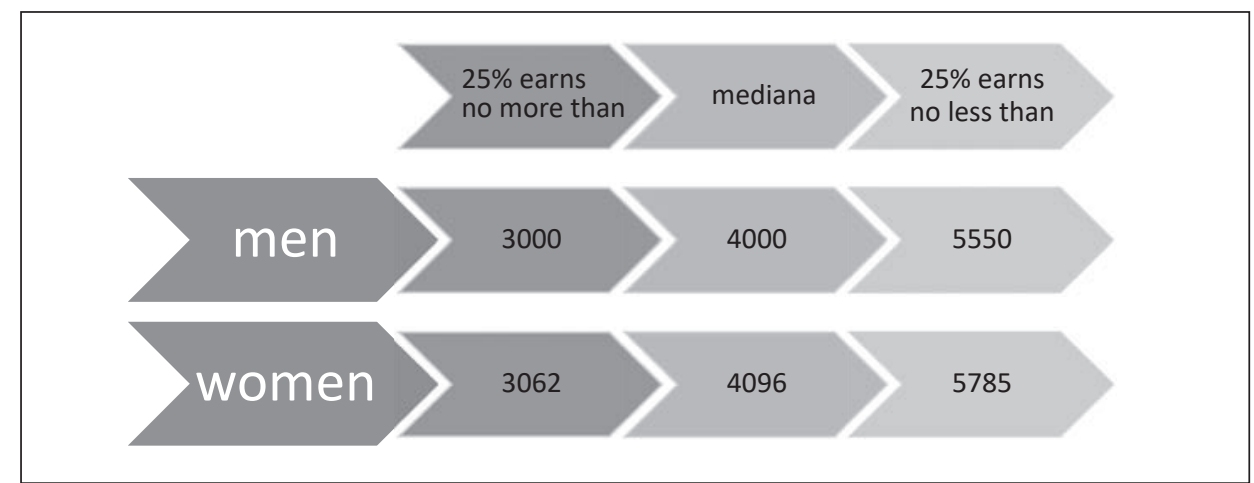

Source: author based on report Salaries in Logistics in 2017, Sedlak \& Sedlak

Moreover, the salary also includes gender and place of work. Against the background of the rest of the country, Warsaw, Poznan and Gdynia have the highest median wages (Sedlak, 2017).

From the perspective of a young person searching the offer of the university at which they would like to gain higher education, is it worth choosing logistics? Apart from the aspect of interest and preferences, it is difficult to categorise and is different for each case, which prompts an answer in the affirmative. It is worth choosing those logistics courses that enable you to acquire appropriate knowledge and practical skills. The statistics prove that the industry is constantly growing, and the only significant problem is the lack of qualified personnel. From the point of view of employees, this is an extremely beneficial situation as business owners wanting to maximise profits will be forced to pay higher remuneration. 
Logistics education at the secondary level

Poland is a country which, not only because of its geographical location but also its educated staff, makes a perfect place for the development of logistics. The demand for transport and storage services increases the internationalisation of business activities, creating jobs for logistics graduates at the same time. In Poland, the system of technical education is based on the idea that it should include both in theoretical and practical knowledge and this results in a rapidly growing economy with a better chance of changing jobs. Poland offers a wide range of logistics training opportunities, not only at a higher level but also in secondary education and post-secondary training in the form of courses or certificates. The three most popular logistics professions among young people are a freight forwarder technician, logistics technician, and port and terminal operation technician. These courses have around 49000 school students, and about 5000 graduates. Between 2010-2017, systemic changes in technical education took place with technical secondary schools lasting five years. In addition, in the 2017/2018 school year, recruitment to the first level of 'industry colleges' began, for which the profession of warehouseman logistics technician appeared in the list of professions (in all post-secondary schools, logistic training has been terminated). Figure 1.4 shows the number of schools that train in logistics specialisations.

\section{Higher and postgraduate logistics education in Poland}

In 2016-2017, no significant quantitative changes in the field of logistics education occurred in higher education. Table 1.1. presents detailed data from the research where non-state universities have more participation in logistics education than state ones. It is

Figure 1.4. Number of Polish schools with logistics specialisations

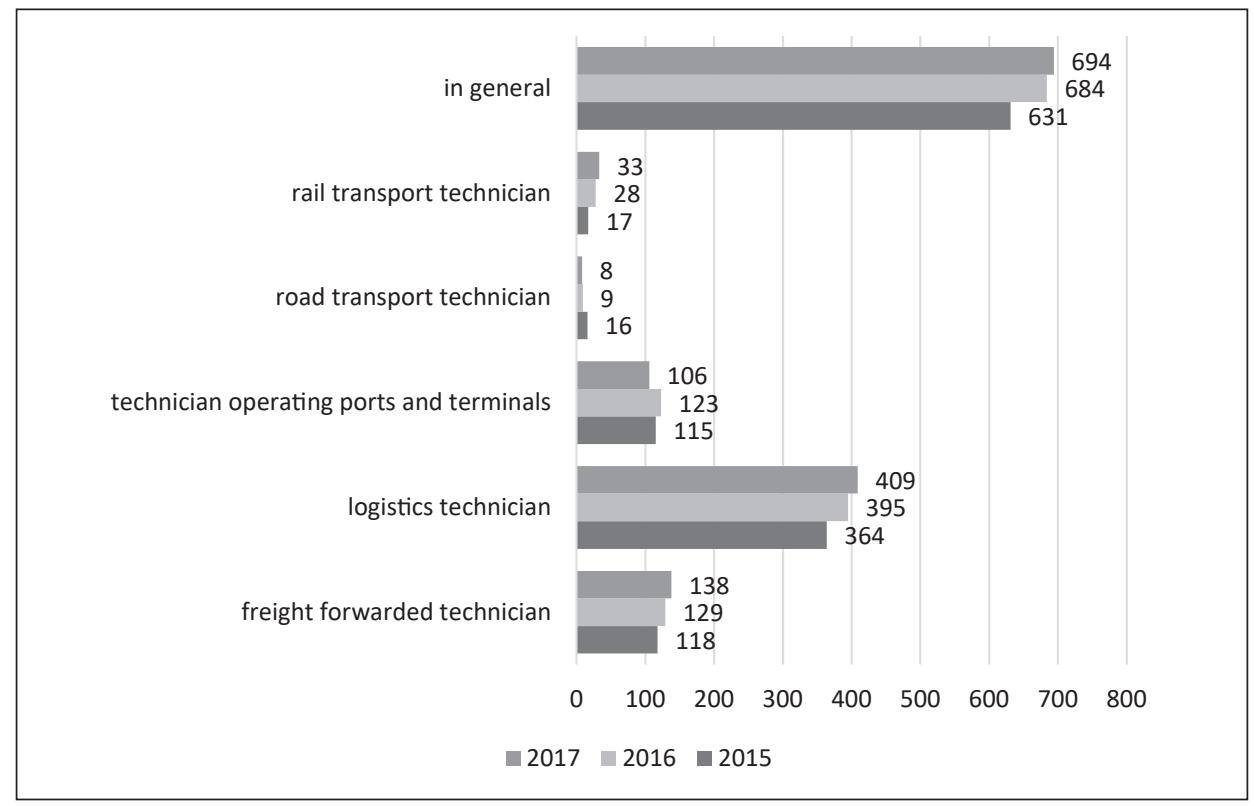

Source: http//depot.ceon.pl/bitstream/handle/123456789/15762/R17.pdf entered: 13 August 2019 
estimated that in the academic year 2016/2017 both at state and private universities, about 61000 students studied logistics at the first and master's levels in different fields of study. Table 1.1 presents specialisations in state higher education from 2014-2017.

In 2016-2017, no significant quantitative changes in the field of logistics occurred in Polish higher education, non-state universities had a greater share than state ones. It is estimated that in the academic year 2016/2017 both in state and private universities, in different fields of study, about 61000 students studied logistics at first and master's levels (yet, there were about 13000 graduates).

Table 1.1. Specialisations in Polish state higher education: 2014-2017

\begin{tabular}{|l|c|c|c|c|c|}
\hline \multirow{2}{*}{ Field of study } & \multicolumn{2}{|c|}{$\mathbf{2 0 1 4 / 2 0 1 5}$} & \multicolumn{2}{c|}{$\mathbf{2 0 1 5 / 2 0 1 6}$} & $\mathbf{2 0 1 6 / 2 0 1 7}$ \\
\cline { 2 - 6 } & \multicolumn{2}{|c|}{ number of majors } & \multicolumn{2}{c|}{ number of majors } & $\begin{array}{c}\text { number of } \\
\text { majors }\end{array}$ \\
\cline { 2 - 6 } & logistics & $\begin{array}{c}\text { with } \\
\text { logistics } \\
\text { subjects }\end{array}$ & logistics & $\begin{array}{c}\text { with logistics } \\
\text { subjects }\end{array}$ & logistics \\
\hline Logistics & 33 & 45 & 34 & 49 & 32 \\
\hline Management & 38 & 48 & 44 & 50 & 53 \\
\hline Transport & 19 & 21 & 21 & 20 & 22 \\
\hline Economics & 17 & 23 & 38 & 24 & 46 \\
\hline Finance and Accounting & 18 & 24 & 21 & 27 & 28 \\
\hline International Relations & 15 & 13 & 16 & 15 & 19 \\
\hline $\begin{array}{l}\text { Management and Production } \\
\text { Engineering }\end{array}$ & 19 & 23 & 27 & 25 & 36 \\
\hline Eurologistics & 7 & 9 & 6 & 8 & 75 \\
\hline
\end{tabular}

Source: author

Postgraduate studies in the field of logistics often make a sufficient source of knowledge and professional preparation, especially for those who have had a similar education before. Figure 1.4 shows the number of universities providing post-graduate studies in logistics in the period 2012-2017.

\section{Logistics training and certification}

In recent years, a growing trend of training centres offering logistics training can be found. The continuous development of logistics caused by the dynamic development of sales through the development of Information Technology and the progressive digitisation of supply chains affects the demand for logistics training. These training courses are not only dedicated to candidates for logistics positions, but also to employees of other sectors in order to raise their professional competences. In 2017, there were 157 training centres and 238 logistics training programs in Poland (Fecher, Szyszka, 2017: 144).

2016-2017 brought a decline in interest in logistics certificates issued by the European Logistics Certification System coordinated by the European Board for Certification in Logistics (EBCL). The main reason was the exhaustion of the European Social Fund, the main source of financing for the training to prepare for certification. In 2017, certification was started according to the new rules of the European Logistics Association based on the 
Figure 1.5. Number of Polish universities providing post-graduate studies in logistics: 2012-2017

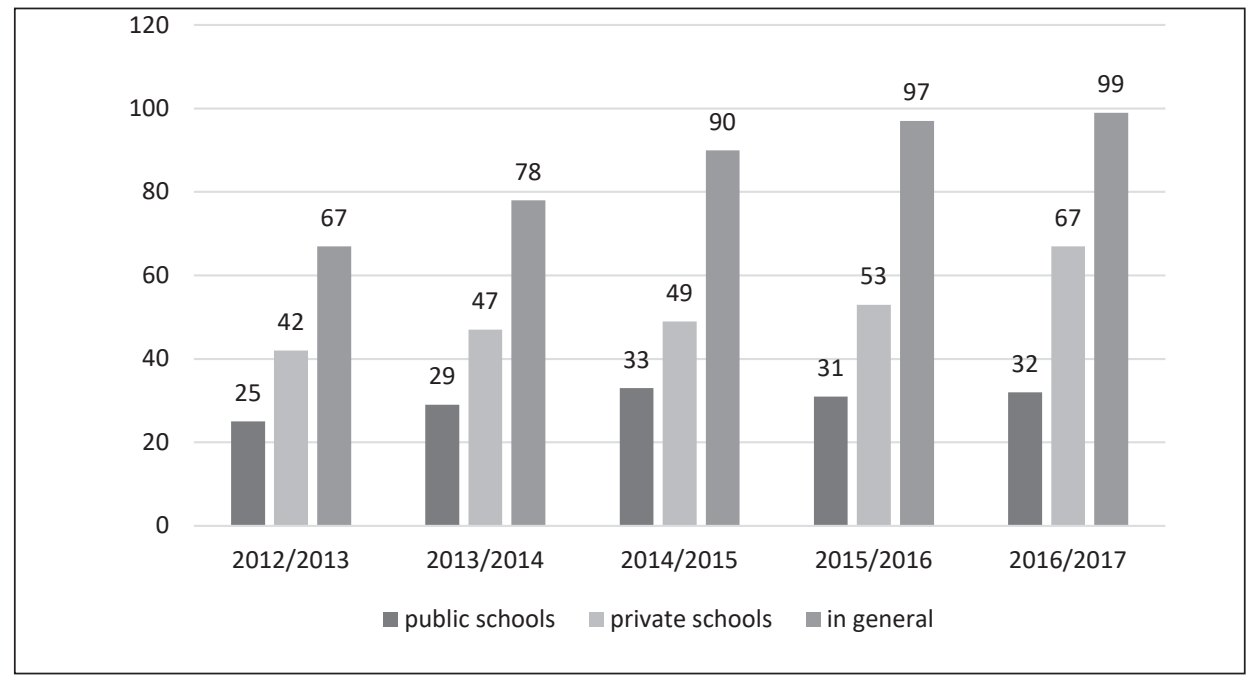

Source: author

guidelines contained in the document: European Qualification Standards for Logistics Professionals (Fecher, Szyszka, 2017: 145).

Owing to the educational reform, which has resulted in the revival of five-year technical secondary education, the number of teaching hours has been increased and enables the better implementation of the curricula. The emergence of the warehouse-logistics profession in the first level of 'industry colleges' will facilitate direct recruitment for warehousing positions, which is an unquestionable opportunity as there is a significant lack of employees in this field.

A growing interest in the profession of rail transport technicians can be expected as some colleges have plans to train drivers who constitute a diminishing group. The growth of universities providing education in the field of logistics and the launch of master's level studies is to be expected. However, much of such a reform will depend on the new law in higher education, as the establishment of faculties requires appropriate human resources, and the new law aims to reduce the number of students at state universities. These activities may cause a drop in the number of logistics students. The number of graduates completing their studies is sufficient, but there is a gap between what potential employees expect from employers and what they can and want to offer. When it comes to the interest of candidates in secondary or higher education, it will depend on the attractiveness of university offers as well as what the labour market can offer. However, observing current trends, it can be assumed that there will be plenty of candidates for logistics as it is the most dynamically developing management science. It is an interdisciplinary field, closely related to marketing and strategic management. The role of logistics services is growing dynamically and its structure has to follow the needs of enterprises implementing international operations. This is the major that teaches the opportunities offered by cooperation between companies, both locally and internationally, and educates future specialists in the planning and implementation of transport and logistics processes. Students gain knowledge in the field of modern logistical systems, system and process approach 
in logistics, cost management of raw materials, products and information, supply logistics, production and distribution, logistics infrastructure, quality assurance processes in logistics.

A graduate of logistics can pride themselves on the following skills:

- making logistics decisions in a business,

- solving logistical problems using engineering methods and techniques,

- designing logistical systems, managing and improving logistics processes,

- applying methods and quality management techniques in logistics processes.

Education in logistics is a new phenomenon in Poland. The author has explored the issue and the description and explanation that prevailed earlier, in terms of education at universities, has shown no major changes. The main reason is the changes to the education system that took place in 2017. According to the data of the Ministry of National Education in logistics education at the end of 2017 the two most popular professions, logistics technician and forwarder, disappeared.

In previous years, no significant quantitative changes in the field of logistics education were observed in higher education. There was a slight drop among non-state universities and slightly higher growth for state universities. However, in higher-level logistics, the share of non-state universities is still greater. Due to the lack of curricula suited to the requirements of the labour market, it makes the interest of potential candidates for universities that offer logistics much smaller than it should be. It is estimated that in the academic year 2016 /2017 in state and non-state universities, in various fields of study, logistics attracted about 61000 students, including approximately 54000 in first level degree courses and approximately 7000 at master's level. In the same academic year, around 13000 graduated. The number of fields in which logistics education is carried out had remained unchanged for two years; there are eight in state universities and six in non-state ones (Fecher, Szyszka, 2017).

Courses related to logistics that can be found at Polish universities include Logistics, Management, Transport, Economics, Finance and Accounting, International Relations, Management and Production Engineering, and finally Eurologistics. However, in the analysed period, the number of logistics specialisations continued to grow. The majority of specialisations can be found in logistics, while the largest number of logistic specialisations is found in European Studies. In the multiplication of courses, it is state universities that definitely excel. Analysis of job offers for specialists in logistics points to an excess of specialisations in relation to the needs of employers. There is a wide variety of study programs at individual universities or rather differentiation of titles (it is possible that a single curriculum could contain from 30 to 50 specialisation subjects).

At postgraduate levels, there is a slight increase in logistics courses due to the fact that it is more flexible, and the curricula more closely reflect the needs of the labour market. In recent years, the number of postgraduate courses in logistics offered by schools has not changed much. Creating postgraduate programs is a more flexible process, and the programs themselves better reflect the needs of the labour markets. Therefore, a slight increase in offers of this type in 2016-2017 was found.

However, not only in a college can students gain an education in logistics. In 20162017, an increase in the number of training centres offering logistics training and the number of training programs could be noticed. The labour market in recent times has shown quite a lot of interest in employees for the logistics sector. Often, however, it turned 
out during recruitment that potential employees do not even have basic knowledge therefore training can be helpful in this area. The training is addressed both to job candidates in the logistics profession as well as to other employees in order to raise their professional competences. This is due to the fact that logistics is constantly changing according to the continuous development of new sales channels and the progressive digitisation of supply chains.

When considering the issue of logistics education, secondary education cannot be forgotten. In the 2016/2017 school year, the three most popular logistics professions among young people were forwarding technician, logistics technician and port and terminal operation technicians, attracting about 49000 students. In the same school year, approximately 5000 graduates completed their studies having completed all the required qualifications and obtained the professional title of a technician. As a result of the reform of the education system, technical schools lasted five years thus returning to the situation before $1999 / 2000$. Since the 2017/2018 school year, recruitment to the first level of 'industry colleges' has begun, for which there has been a logistics challenge in the list of professions. In 2016-2017, there was a sharp drop in the number of post-secondary schools with logistics courses with logistical training almost ceasing.

Yet, the basic question must be asked: what is the situation of young 'logisticians' in Poland today? The future of logistics is the automation of tasks and processes, above all, wherever repetitive or less complicated activities are performed. Solutions automating operations performed in the warehouse are already increasing in popularity. The future is the automation of deliveries with an increasingly bold discussion about automated delivery of shipments or unloading vehicles. This is the future that is knocking on our door. As can be seen, automation and artificial intelligence in logistics is an important element that can lead to many activities performed by humans will successfully be performed by machines in the future. Already, solutions such as transport exchanges or telepathic tools allow actions previously performed in a few hours reduced to a few clicks. In other areas, the spectre of job reductions is more real: Zalando has announced that the issue of algorithms and artificial intelligence will release from 200 to 250 employees in its Berlin branch. Tesla's Gigafactory in the Berlin area seems to be 'manned' mainly by $\mathrm{AI}^{2}$.

\section{Conclusions}

The research has proved that logistics is becoming increasingly popular in Poland and it is undoubtedly worth studying it at all levels of state and private education as well as on additional courses. The logistics sector in Poland is constantly growing. It is certain that in the future this process will continue, and even more intensively due to the impact of e-commerce. The TSL industry needs a large number of candidates for work experienced in this field, which is why Polish students decide to choose the field of international logistics. Description of logistics education in Poland, as well as evaluation, concerns strengths and weaknesses.

When technical training is concerned many changes have been noted, resulting mainly from a change in the education system. According to data from the Ministry of National Education, at the end of 2018, many very popular logistics courses disappeared from some

\footnotetext{
2 "Obserwator Finansowy", 2019.
} 
post-secondary schools namely logistics technicians as well as forwarding technicians.

The next few years remain in question due to the reforms implemented in higher education which may affect logisticians. A great interest in logistics manifests itself in secondary schools, justified as leavers from such schools have no problem finding employment, and employers are still pointing to a shortage of qualified staff on the market. Changing the course of teaching from four to five years will allow the teaching staff to prepare their students more specifically and in a broader up-to-date way. A great opportunity for students of high schools is to participate in the Nationwide Logistics Olympiad, which can be a pass to a dreamed-of study and career. Training is also very popular, but due to costs, the number of certificates issued is still falling.

In comparison to educational offers in the field of logistics, Poland is still lagging behind developed European countries such as Germany which have specialised facilities for training staff in logistics in the widest sense.

\section{References}

Babbie, E. (2013). Podstawy badań społecznych. [Basics of social research]. Warszawa: Wydawnictwo Naukowe PWN.

Centrum Kształcenia Podyplomowego. Uczelnia Łazarski (2019, 3 September). Studia podyplomowe. Retrieved from: https://ckp.lazarski.pl/pl/studia-podyplomowe/akademia-menedzera/zarzadzanie-lancuchem-dostaw-w-dobie-digitalizacji/

e-bit Sieć Badawcza ŁUKASIEWICZ - Instytut Logistyki i Magazynowania. https://www.e-bit.edu.pl/onas

Fajczak-Kowalska, A., Kowalska, M. (2018). Ocena stanu sektora TSL w Polsce - lata 2004-2017. [Assessment of the condition of the TSL sector in Poland - 2004-2017]. Logistyka. Autobusy, 12, 886-889.

Fecher, I., Szyszka, G. (2017). Logistics in Poland - Report 2017. Biblioteka Logistyka.

Gorynia, M., Jankowska, B, Maślak, E. (2000). Branża jako przedmiot badań w ekonomii. [The industry as an object of research in economics.] Gospodarka Narodowa, 2, 36-54.

Gradowicz, C. (2011). The Systems of Education in Shaping the Creative Staff for Logistic. Acta Universitatis Lodziensis. Folia Oeconomica, 251, 175-192.

Institute of Logistics and Warehousing Publishing. https://www.ilim.poznan.pl/english-version

Januła, E., Truś T., Gutowska, Ż. (2011). Spedycja [Shipping]. Warszawa: Difin.

Jeszka, A.M. (2009). Sektor ustug logistycznych $w$ teorii i praktyce. [Logistics services sector in theory and practice]. Warszawa: Difin.

Obserwator Finansowy, wydania 2019.

Pilch, T., Bauman, T. (2001). Zarys badań pedagogicznych. Strategie ilościowe i jakościowe. [Outline of pedagogical research. Quantitative and qualitative strategie]. Warszawa: Wydawnictwo Akademickie Żak.

Sedlak \& Sedlak (2019, 12 June). Salaries in logistics in 2017. Retrieved from: https://wynagrodzenia.pl/ raport-placowy/wynagrodzenia-w-logistyce-w-2017-roku

Skarżyński, M. (2009a; 2019, 13 August). Chauncey B. Baker - definicja logistyki [Chauncey B. Baker - Logistics definition]. Retrieved from: https://www.logistyka.net.pl/bank-wiedzy/pozostale-zagadnienia/item/6707-chauncey-b-baker-definicja-logistyki

Skarżyński, M., (2009b; 2019; 13 August). Antoine Henri Jomini - XIX-wieczny i praktyk logistyki. Antoine Henri Jomini - 19th century logistics practitioner]. Retrieved from: https://wwwlogistyka. net.pl/bank-wiedzy/pozostałe-zagadnienia/item/6133-antoine-henri-jomoni-xix-wieczny-teoretyk-i-praktyk-logistyki entered: 13 August 2019

TransEdu. https://edu.trans.eu 
Transport and Logistics Trends 2019, Five forces transforming the industry in Central and Eastern Europe. PwC CEE Transport and Logistics Trend Book 2019

Wiedza: Raporty i analizy. [Knowledge: Reports and analyzes]. (2019; 12 June). Retrieved from: https:// www.logistyka.net.pl/bank-wiedzy/raporty-i-analizy/item/downald/79665_748e4c496

Wojciechowski, A. (2012). Rynek usług logistycznych w Polsce - analiza, perspektywy rozwoju. [Logistics services market in Poland - analysis, development perspectives]. Logistyka, 4, 1382-1395.

Wzrośnie zatrudnienie w logistyce. [Employment in logistics will increase]. (2019, 12 June). Retrieved from: https://www.propertynews.pl/magazyny/wzrosnie-zatrudnienie-w-logistyce,69441html

Jolanta Maroń, PhD, Cracow University of Economics, Faculty of International Management. Research interests include issues related to international management, leadership in international management, international logistics, AI in logistics, logistics education, New Silk Road logistics.

ORCID: 0000-0001-5526-4407

\section{Adres/Address:}

Uniwersytet Ekonomiczny w Krakowie

Katedra Zarządzania Międzynarodowego

ul. Rakowicka 27

31-510 Kraków, Poland

e-mail: zajacjol@uek.krakow.pl 